\title{
Geochemical interactions between the water, suspensate and soil of the mangrove forest as a process of fertilization in Bragança, Northern Brazil Interações geoquímicas entre água, suspensato e solo em ambiente de mangue como processo de fertilização em Bragança, Norte do Brasil
}

\author{
Sérgio Brazão e Silval', Marcondes Lima da Costall \\ 'Universidade Federal Rural da Amazônia. Belém, Pará, Brasil \\ "Universidade Federal do Pará. Belém, Pará, Brasil
}

\begin{abstract}
This study evaluated the changes in soil fertility mangrove after immersion in distilled water, present in the estuary of the Caeté river. In experiments, soil was immersed in distilled water, and determined periodically $\mathrm{pH}$ and Eh and available concentrations of $\mathrm{Ca}, \mathrm{K}, \mathrm{Cu}$, Fe, P and organic C for a period of 132 days. The soils and suspensate had a similar composition, quartz, kaolinite, illite, and smectite, as well as anatase as an accessory mineral. Immersion provoked profound alterations in the fertility of the soil promotion the release of Fe and P, and changes in the availability of Ca, K and Cu. Carbon was consumed during the experiment, reducing its concentration. The $\mathrm{pH}$ changes from high acidity to medium acidity while the oxidized environment has changed for reduced environment for Eh -281.25 in 132 days of flooding. The study confirmed that the local gleisols are highly fertile, presence of 2:1 clay minerals and high levels of organic carbon who contributed to the considerable fertility of this soil. The study also indicates the importance of the suspensate for the maintenance of the fertility of the soil, given its high levels of exchangeable cations and available phosphorus.
\end{abstract}

Keywords: Amazon lowland. Surface geochemistry. Waterlogged soil. Mangrove soil. Soil fertility.

Resumo: Este estudo avaliou as alterações na fertilidade do solo de mangue após imersão em água destilada, presente no estuário do rio Caeté. Na experimentação, o solo foi imerso em água destilada, sendo determinados periodicamente o pH e o Eh e as concentrações disponíveis de Ca, K, Cu, Fe, C e P durante um período de 132 dias. Os solos e suspensatos apresentam composição semelhante de quartzo, caulinita, illita e esmectita, bem como anatásio como um mineral acessório. A imersão provocou alterações profundas na fertilidade do solo, promovendo a disponibilização de Fe e P e alterações na disponibilidade de $\mathrm{Ca}, \mathrm{K}$ e $\mathrm{Cu}$. $\mathrm{O}$ carbono foi consumido durante o experimento, diminuindo sua concentração. $\mathrm{O}$ $\mathrm{pH}$ alterou-se de acidez elevada para acidez média, enquanto o ambiente oxidado alterou-se para ambiente reduzido, a Eh -281,25 em 132 dias de inundação. O estudo confirmou que os gleissolos locais são altamente férteis e a presença de minerais 2:1 e altos níveis de carbono orgânico contribuíram para a fertilidade considerável desse solo. $\bigcirc$ estudo indica também a importância do suspensato para a manutenção da fertilidade do solo, tendo em conta os seus níveis elevados de cátions permutáveis e de fósforo disponível.

Palavras-chave: Várzea amazônica. Geoquímica de superfície. Solo alagado. Solo de mangue. Fertilidade do solo.

SILVA, S. B. \& M. L. COSTA, 2016. Geochemical interactions between the water, suspensate and soil of the mangrove forest as a process of fertilization in Bragança, Northern Brazil. Boletim do Museu Paraense Emílio Goeldi. Ciências Naturais 10(3): 381 -397.

Autor para correspondência: Sérgio Brazão e Silva. Av. Presidente Tancredo Neves, n 2501. Belém, PA, Brasil. CEP 66070-901 (sergio.brazao@ufra.edu.br).

Recebido em 11/11/2013

Aprovado em 17/04/2016

Responsabilidade editorial: Mário Augusto G. Jardim

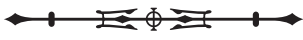




\section{INTRODUCTION}

The characteristics acquired by soils following inundation have been described by a number of authors (Ponnamperuma, 1972; Fageria, 1984; Camargo et al., 1999; Assis et al., 2000; Otero et al., 2009). In general, the flood appears to have potential benefits for the fertility of the soil, such as an increase in $\mathrm{pH}$ and reduction in Eh. Water is present naturally in the profile of the soils of the estuary of the Amazon River, which has unique properties, including high fertility, with two types of soil being especially abundant haplic gleisol in the freshwater floodplains, and salic gleisol in the mangrove sediments.

The effects of inundation on the local haplic gleisol, which is abundant on the lower stretches of the rivers of the Amazon estuary, have been analyzed experimentally in short- (Silva et al., 1996; Ferreira et al., 1998; Mattar et al., 2002; Silva, 2005) and the need for definitive answers prolonged flood. The latter study focused on the sediments of the floodplain of the Guamá River adjacent to the city of Belém, and investigated the effects of flooding on the haplic gleisol, and the contribution of the mineralogical components of the suspended sediments of the water of this river (the suspensate) to the formation of these plains and, subsequently, their soils. The results indicated that flooding contributed to an increase in the fertility of the soil, for which organic matter and 2:1 clay minerals, which are present in this soil and the suspended material, were the principal agents.

In an overview of the formation of mangrove soils, Ferreira et al. (2007) concluded that the pedogenetic processes involved are subsequent to the colonization of the habitat by plant species adapted to the local conditions. These soils are typically gleisols, quartzarenic or alluvial typics or podzols (Prada-Gamero et al., 2004).

In the coastal region of Pará, however, salic gleisols predominate, as shown in Ferreira \& Botelho (1999) study of the estuary of the Morcegos River adjacent to the city of Marapanim. In this study, the effects of flooding were tested using distilled water over a 45-day period, so the role of the mineralogical composition of the soil or the suspended material in the water that floods the mangrove was not taken into account. Despite the short period of this study, it demonstrated an increase in fertility (availability of nutrients) and increased $\mathrm{pH}$.

Mangroves are important not only in terms of the extension of the area they occupy, but also because of their environmental and social relevance. In Brazil, they cover a total area of $13,000 \mathrm{~km}^{2}$, extending from Laguna, in the state of Santa Catarina, to northern Amapá. This area corresponds to approximately half of the mangroves found in the Americas (Burke et al., 2001; Souza Filho, 2005). In the state of Pará, the soils of the mangrove, which is also known as a fluvial-marine swamp, extend between the mouths of the Para and Gurupi rivers, that is, along the whole of the length of the state's northeastern coastline. This region is known locally as the Salgado zone (Lima \& Tourinho, 1995; Lima et al., 2001), and is classified as a macrotidal mangrove coast (Souza Filho, 2005). These mangroves represent $56.6 \%\left(7,591 \mathrm{~km}^{2}\right)$ of the total area of this type of ecosystem in Brazil, and constitute the largest continuous tract of mangrove forest anywhere in the World.

Mangrove forests represent an important ecosystem in tropical coastal regions, and are characterized by a specific flora, adapted to these swampy environments immersed in brackish waters of moderate to high salinity (ShaefferNovelli, 1999). These habitats are an economically important source of animals such as mussels (Mytilus edulis), oysters (Ostrea edulis), shipworms (Neoteredo reynei), shrimp (Macrobrachium carcinus), marine crabs (Scyla serrata), and mangrove crabs (Ucides cordatus), as well as numerous fishery resources (Furtado et al., 2006), that are essential to the subsistence of the local human population, which exports the excess production to other regions around the country. Mangrove forests also play an important role in the capture of atmospheric carbon, with an index of $210 \mathrm{~g}$ of $\mathrm{CO}_{2} \mathrm{~m}^{-2} \mathrm{yrd}^{-1}$ (Chmura et al., 2003; Otero et al., 2009; Kristensen et al., 2008).

The exuberant mangrove vegetation of the region of Bragança includes trees that may reach $30 \mathrm{~m}$ in height and 
a meter in diameter, although the biological diversity of this ecosystem is naturally much lower than that found in typical Amazonian mainland forest, or even its freshwater swamps. This hydromorphic environment, which is dominated by a subsaline, muddy substrate, with a tendency for the predominance of reducing conditions, is highly unfavorable for most plant species. The tree species adapted to this environment are the red mangrove (Rhizophora mangle L.), the white mangrove (Laguncularia racemosa L.), the black mangrove (Avicennia sp. L.), and the button mangrove (Conocarpus erectus L.) (Vilhena et al., 2010). In these species, the seeds germinate while still attached to the mother-plant, which guarantees their pre-development before they are immersed in the saline hydromorphic substrate below the tree. The leaf litter accumulating beneath these trees determined the black and grayish coloration of the soil profile (Citrón \& Schaeffer-Novelli, 1983). In environmental transition between mangrove and lowland, with several kilometers long, the vegetation changes to floodplain forest, where local people plant rice. Although grown without the use of agronomic techniques, get high yields ( 3.5 to $4 \mathrm{t} / \mathrm{ha}$ ), with maintenance of this productivity for decades.

The present study evaluates the dynamics of nutrients between soil geochemistry, water and suspensato, affecting the fertility of this soil in the mangrove soils of Bragança, in northern Brazil, when immersed under distilled water.

\section{MATERIALS AND METHODS}

Samples of the soil and suspended material (suspensate) were collected from the estuary of the Caeté River, which feeds into part of the mangrove system of Bragança, in order to examine the possible relationship between them. Soil samples were collected with two objectives, to (i) characterize the soil profile suspended material, the suspensate, and (ii) conduct an experimental analysis of the effects of the immersion of the soil with distilled water, in order to evaluate the adsorption and desorption capacity of the soil in relation to the chemical elements that determine its fertility. The present study was based on the methods used by Silva et al. (2015), Mattar et al. (2002) and others, to evaluate the geochemical transformations of a haplic gleisol on the estuarine floodplain of the sediment-laden Guamá River.

The characterization of the soil was held in Profile and each sample was designated according to its horizon: $A_{1}$ for depths of zero to $36 \mathrm{~cm}, A C$ for those between $36 \mathrm{~cm}$ and $75 \mathrm{~cm}$, and $C_{g}$ for depths of 75 to $180 \mathrm{~cm}$, totaling three samples. The lower limit of the latter category is only an estimate, given the rapid flooding of the hole excavated for the collection of samples, which impeded the reliable visualization of its bottom. The sample denominated EXP-01 was composed of 65 separate samples collected with a Dutch auger from the upper 20 $\mathrm{cm}$ of horizon $\mathrm{A}_{1}$, the stratum from which plants normally extract their nutrients. The samples, which each weighed around $1.5 \mathrm{~kg}$, were distributed randomly within an area of approximately $10,000 \mathrm{~m}^{2}$. The 65 samples were mixed and homogenized, and then air-dried, crushed with a wooden roller and allocated to experimental lots.

Samples were collected in the rural zone of the municipality of Bragança, on the estuary of the Caeté River, approximately $5.2 \mathrm{~km}$ from its mouth (location of the profile: $0^{\circ} 50^{\prime} 38.38^{\prime \prime} \mathrm{S}, 46^{\circ} 38^{\prime} 51.67$ " W), close to the highway that links Bragança to the coastal village of Ajuruteua (Figure 1). The vegetation at the site is exuberant, and includes the principal tree species - Rhizophora mangle L. (red mangrove), Laguncularia racemosa L. (white mangrove), and Avicennia sp. L. (black mangrove) - found in this region.

The sample of suspended material, SUSP-01, was subtracted from water collected from the left margin of the Caeté River (location of the sampling station: $0^{\circ} 50^{\prime}$ 43.33" S, 46 38' 53.12" W), 140 meters from the location of the soil profile. A total of approximately 600 liters of water was collected in three 200-l polyethylene containers, which were left to decant naturally (without the addition of flocculant) for three months. The supernatant was then removed and the remaining material was transferred to a 
smaller container and decanted and centrifuged a second time. The solid residue, or suspensate, was transferred to a desiccator for 24 hours. A total of $12,677 \mathrm{~g}$ of suspensate was obtained. The fertility of this sample was analyzed, including the identification of available chemical elements, mineralogical analysis by $\mathrm{X}$-ray diffraction, and the determination of the total chemical composition.

The soil samples were subjected to the following analyses:

1) Granulometric analyses of sample EXP-01 by the sieving and pipette method, as described by EMBRAPA (1997) in the UFRA laboratories;

2) Analysis of fertility, based on Silva (2009), for the three samples of the soil profile $\left(A_{1}, A C, C_{g}\right)$ and the EXP-01 and SUSP-01 samples, in the UFRA laboratories;

3) Mineralogical analysis of the EXP-01 and SUSP-01 samples by $\mathrm{X}$-Ray Diffraction (XRD) including the total sample, powder method, clay fraction with oriented blades for the precise characterization of the minerals in the clay (Moore \& Reynolds Jr., 1997). An $X$ 'Pert Data Collector diffractometer (version 2.1a) was used for the collection of the data, which were processed in the X'Pert HighScore software (version 2.1b) for the confirmation of the minerals;

4) The samples of the upper $\left(A_{1}\right)$ and lower horizons $\left(C_{g}\right)$ and the suspended material were used for total chemical analyses (major, minor, and trace elements) in order to verify genetic affinities between the samples, as well as to evaluate their contribution as a source of nutrients. The Inductive Coupled Plasma - Mass Spectrometry (ICP-MS) analyses were conducted at the Acme Analytical Laboratories Ltd. in Vancouver, Canada.

The experimental procedure was carried out in the Chemical Analyses Laboratory of the UFPA Geosciences Institute. A subsample of $28 \mathrm{~kg}$ of sample EXP-01 was divided into four lots, which were placed in four

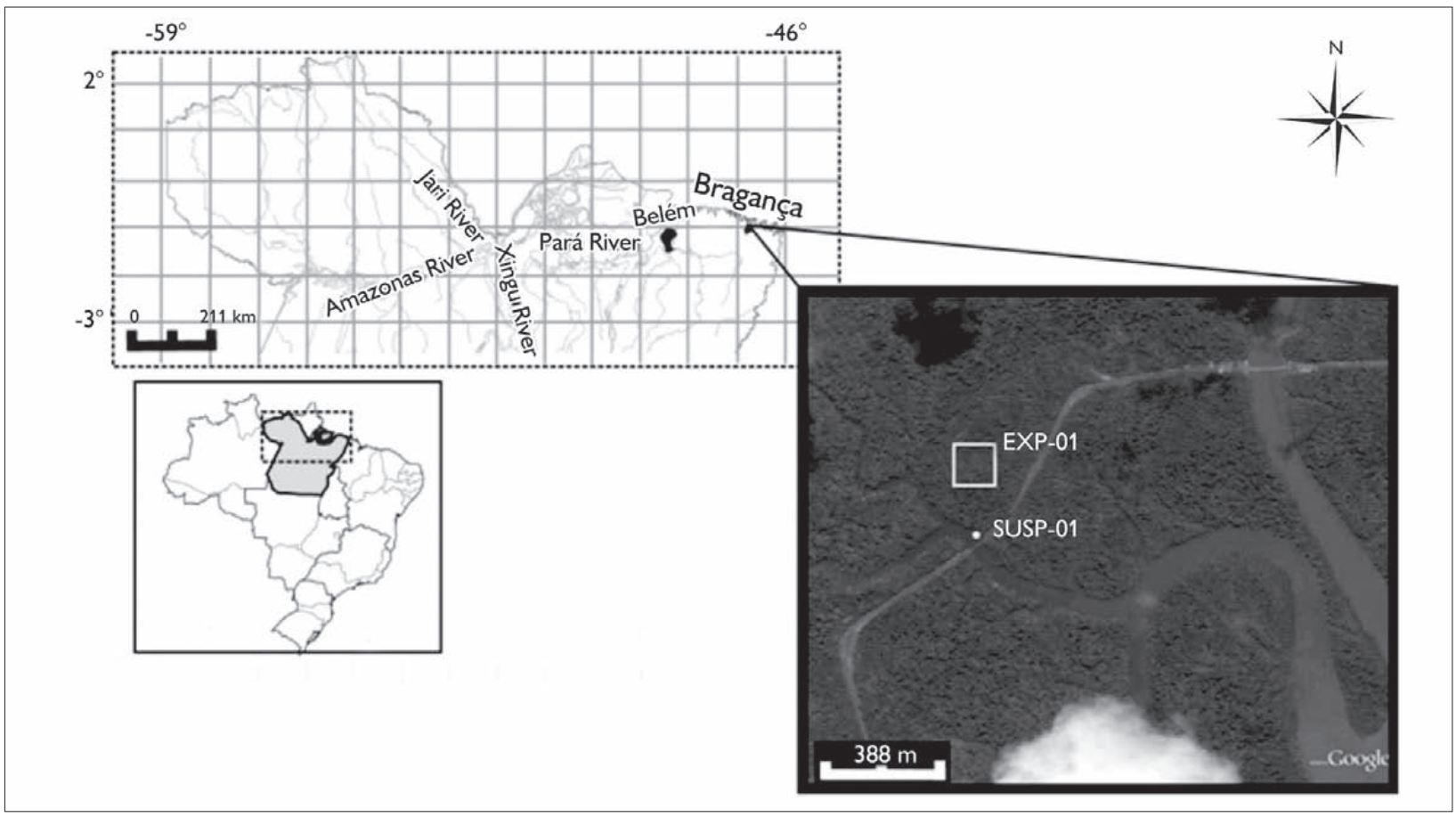

Figure 1. Location of the study area in the rural zone of the municipality of Bragança on the northeastern coast of the Brazilian state of Pará, and the locations at which soil ( $\left.0^{\circ} 50^{\prime} 38.38^{\prime \prime} \mathrm{S}, 46^{\circ} 38^{\prime} 51.67^{\prime \prime} \mathrm{W}\right)$ and water samples ( $\left.0^{\circ} 50^{\prime} 43.33^{\prime \prime} \mathrm{S}, 46^{\circ} 38^{\prime} 53.12^{\prime \prime} \mathrm{W}\right)$ were collected.

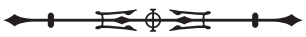


7-l Styrofoam boxes. Each box was filled with distilled water up to a depth of $2 \mathrm{~cm}$ above the upper limit of the sample, which was topped up to maintain the level as the water evaporated. Samples were taken from the immersed soil in the four boxes every day over the first five days of immersion, and then at irregular intervals, varying from one to 15 days over the subsequent days. The shorter interval during the initial sampling was important because the greatest variation tends to occur during the first few days of immersion (Ponnamperuma, 1972). The samples were collected on alternating days during the first month of the experiment, and then at gradually increasing intervals until a maximum of 15 days, with a total of 100 samples being collected. The experiment lasted 132 days, except for the analysis of carbon, which was continued until the 276th day. For each sample, the physical-chemical parameters $\mathrm{pH}$ and Eh were measured using a potentiometer, and the concentrations of available $\mathrm{P}$ and exchangeable $\mathrm{Ca}, \mathrm{K}$, $\mathrm{Zn}, \mathrm{Mn}, \mathrm{Cu}$, and Fe were determined. The levels of the latter ( $\mathrm{Ca}, \mathrm{K}, \mathrm{Zn}, \mathrm{Mn}, \mathrm{Cu}$, and $\mathrm{Fe}$ ) were determined by atomic absorption, $\mathrm{P}$ by spectrophotometry, and organic carbon by the Walkley-Black method (EMBRAPA, 1997).

The available levels of the nutrients in the samples were determined based on the development of a specific analytical procedure for their collection and analysis. The preparation of the samples for these analyses normally began with the drying of the soil, followed by crushing and, in some cases, grinding, followed by sieving through a $2 \mathrm{~mm}$ mesh. As mentioned above, the transformations occurring in the soil while immersed revert to the conditions presented by the aerobic soil when it is dried. Given this, the alterations that may have occurred in the $\mathrm{pH}$, Eh, and nutrient availability are modified to aerobic conditions, which may be considerably different from the conditions presented by the environment at the moment of sampling. In order to obtain results consistent with these humid conditions, the analyses were conducted on the humid soil, as recommended by Silva et al. (1996); Ferreira et al. (1998); Ferreira \& Botelho (1999); Mattar et al. (2002); and Silva at al. (2015).
For this, the samples removed from the experimental lots included $10 \mathrm{ml}$ of humid soil, which were weighed and analyzed. To convert the results obtained from this humid analysis to those of dry soil, a humidity factor was obtained. For this, a new humid sample was taken, which was dried at $105^{\circ} \mathrm{C}$ in a stove followed by a period in a desiccator, before weighing. The correction factor was based on the difference between the humid and dry weights. This factor was used to adjust the results obtained from the analysis of the humid soil, for the dry weight in grams.

\section{RESULTS AND DISCUSSION}

\section{MINERALOGY, FERTILITY, AND GRANULOMETRY}

The gleisol analyzed in the present study is composed of quartz, kaolinite, illite, smectite, and anatase, in decreasing order of abundance (Figure 2). The suspended material consisted of these same minerals, although in a slightly different order of abundance - quartz, kaolinite, smectite, illite, and anatase (Figure 3). The halite identified in the sample must represent the precipitation of the salts dissolved in the water, following the drying of the sample.

As retainers of cations, smectite and illite are of particular importance for the fertility of this soil, and are present in both the soil itself and the suspended material, indicating that the former was supplied by the latter. The suspended material of the Caeté River is derived from the erosion of the river bed and the re-suspension of the finer particles during the ebb and flow of the tidal currents.

In addition to these minerals, Costa et al. (2004), Silva (2005), Berredo et al. (2008), and Vilhena et al. (2010) have identified K-feldspar, pyrite, halite, and jarosite in mangrove sediments from the same region, and concluded that they were of autologous origin. However, the smectite found in the suspended material must be derived from the sediments of the regional substrates that contribute to the discharge of the rivers that form the Amazon estuary. Smectite represents $48 \%$ and kaolinite, $24 \%$ of the clay minerals of the upper 10 $\mathrm{cm}$ of the mangrove soils of Bragança (Costa et al., 2004).

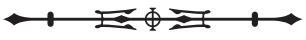



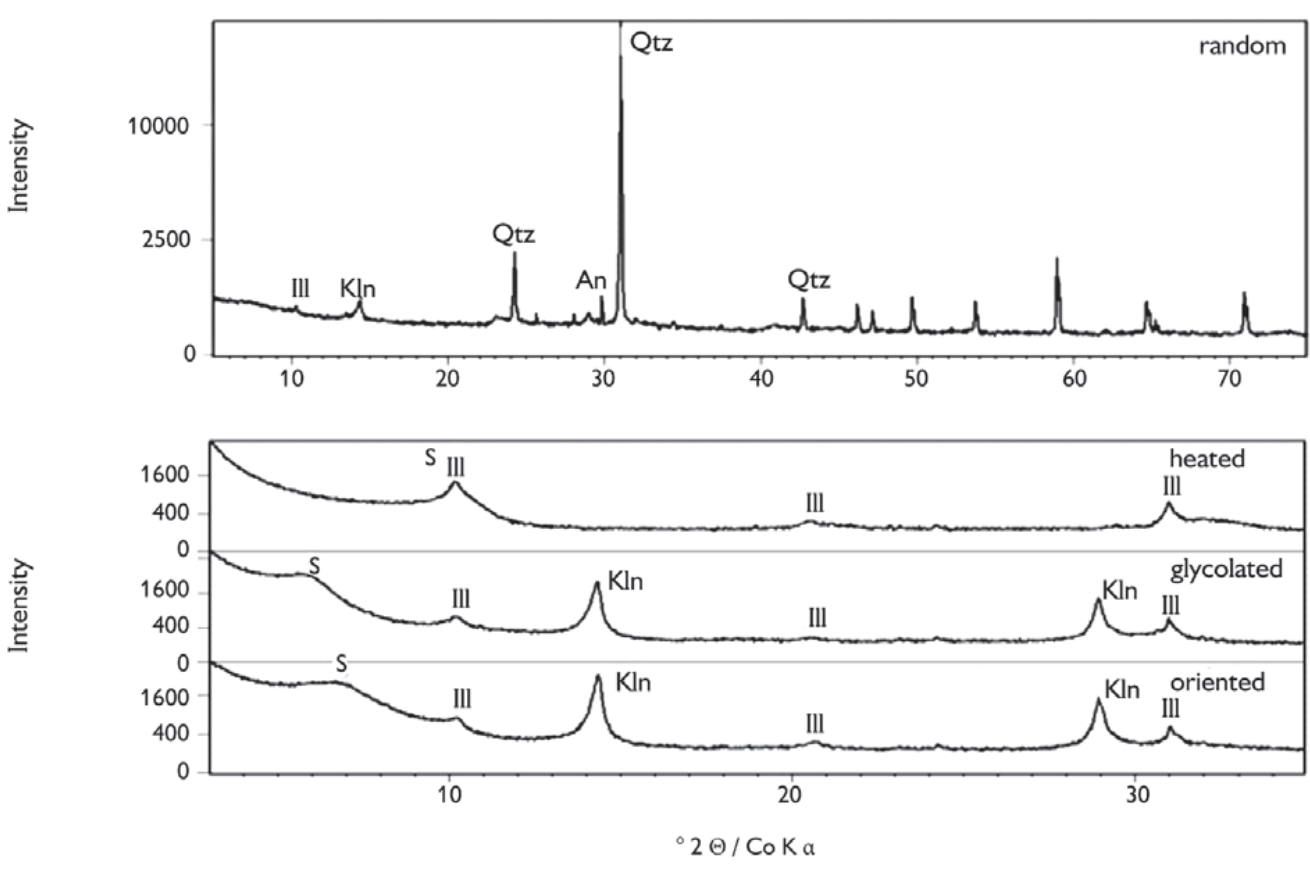

Figure 2. Patterns of $\mathrm{X}$-ray diffraction obtained for the soil samples and the respective oriented fractions of the clay minerals, with the principal mineral phases being identified as: smectite (S), illite (Ill), kaolinite (Kln).

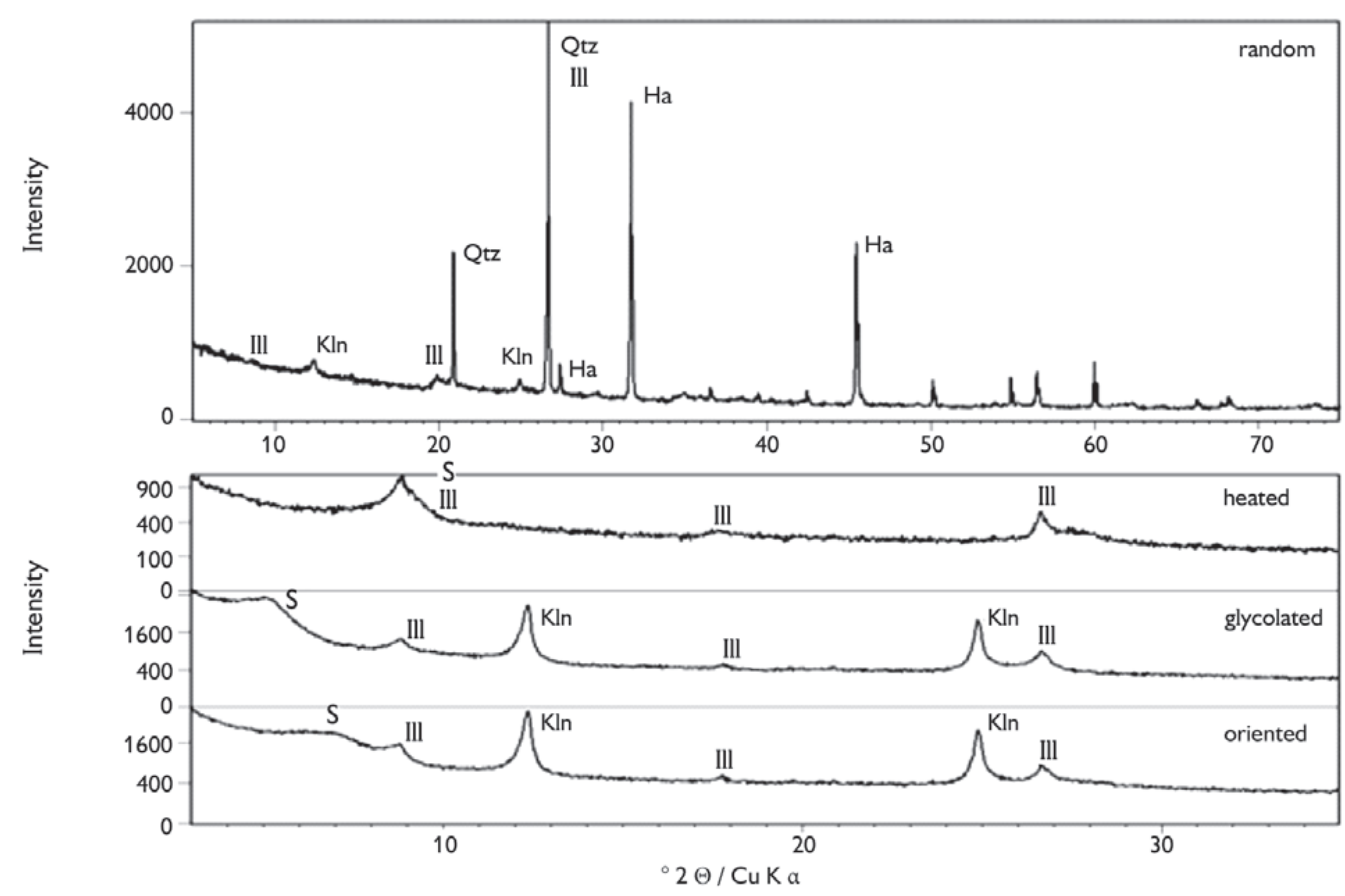

Figure 3. Patterns of $X$-ray diffraction obtained for the sample of suspended material and the respective oriented fractions of clay minerals, with the principal mineral phases being identified as: smectite (S), illite (Ill), and kaolinite (Kln).

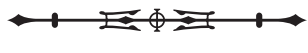


In addition to these minerals, the soils analyzed here are rich in organic material, varying from $18.14 \mathrm{~g} / \mathrm{dm}^{3}$ in the $A_{1}$ horizon to $45.67 \mathrm{~g} / \mathrm{dm}^{3}$ in the $C_{g}$ horizon, values much higher than those recorded for the haplic gleisol of the Guamá River (Silva, 2008). The organic material, together with the 2:1 clay minerals, which are abundant in these sediments, is important for the soil's cation exchange capacity (CEC).

The results of the analysis of the fertility of the soils and the suspended material indicate that both are fertile, although more so in the case of the suspensate, in which there was considerable base saturation and extremely high concentrations of phosphorus. The greater abundance of 2:1 clay minerals in the suspended material undoubtedly contributed to the fixation of cations, but more importantly, the fact that, as these minerals have yet to be consumed by the plants, they remain adsorbed in the suspended material, allowing their transportation and deposition. This indicates the fundamental importance of this suspended material for the maintenance of the fertility of the soil, through the incorporation of both the solid component (the sediment/suspensate) and the water, which contains dissolved nutrients, during the tidal cycle.

The total chemical analysis of the salic gleisol recorded a concentration of $0.10 \%$ of $\mathrm{CaO}$ in the superficial layer, and $0.31 \%$ in the $C_{g}$ horizon, with $0.47 \%$ and $1.69 \%$ of total $\mathrm{MgO}$ in the $\mathrm{A}_{1}$ and $\mathrm{C}_{\mathrm{g}}$ horizons, respectively. Similarly, potassium was present in the form of $\mathrm{K}_{2} \mathrm{O}$, with a concentration of $0.72 \%$ in the $\mathrm{A}_{1}$ horizon, and $1.70 \%$ in the $\mathrm{C}_{\mathrm{g}}$ horizon. Typically, in Amazonian soils, the total levels of these elements, even when relatively high, do not reflect the available levels. In the present case, however, the available levels of calcium and magnesium, and even those of potassium, are relatively high (Table 1), both in the soil and the suspended material.

Phosphorus is an interesting example of this phenomenon. The total values for this element were $0.05 \%$ of $\mathrm{P}_{2} \mathrm{O}_{5}$ in the $\mathrm{A}_{1}$ horizon, and $0.09 \%$ in the $\mathrm{C}_{\mathrm{g}}$ horizon. The levels of available phosphorus were relatively high, however, in both the soil $\left(20.67 \mathrm{mg} / \mathrm{dm}^{3}\right)$ and suspended material $\left(86.58 \mathrm{mg} / \mathrm{dm}^{3}\right)$, indicating the occurrence of a continuous renovation of this element in the soil. This would occur daily through the influx of the tides, bringing suspended material rich in chemical nutrients.

The $\Delta \mathrm{pH}$ indicates the predominance of negative charges in all the horizons, emphasizing the importance of the $2: 1$ clay minerals observed during the study for the retention of cations. This explains the relatively high values for CEC. Aluminum, which presented total values of $5.35 \%$ of $\mathrm{Al}_{2} \mathrm{O}_{3}$ in the $\mathrm{A}_{1}$ horizon, and $16.52 \%$ in the $\mathrm{C}_{\mathrm{g}}$ horizon, did not participate actively in the saturation complex, with only $0.26 \%$ of saturation in the $A_{1}$ horizon and $3.21 \%$ in the $C_{g}$ horizon (Table 1 ), which were fully occupied by nutrients, presenting $88.64 \%$ base saturation in the $A_{1}$ horizon and $81.60 \%$ in the $\mathrm{C}_{\mathrm{g}}$ horizon.

Table 1. Parameters of fertility recorded during the present study, including the concentrations of available and exchangeable elements in the samples of soil and suspended material from Caeté River. Obs: the A, sample (equivalent to EXP-01) had the following granulometric composition: coarse sand $=105.80 \mathrm{~g} / \mathrm{kg}$; fine sand $=528.30 \mathrm{~g} / \mathrm{kg}$, silt $=76.60 \mathrm{~g} / \mathrm{kg}$ and clay $=298.3 \mathrm{~g} / \mathrm{kg}$. Legends: CEC $=$ cation exchange capacity; $\mathrm{V}=$ base saturation percentage; $\mathrm{m}=$ aluminum saturation percentage.

\begin{tabular}{|c|c|c|c|c|c|c|c|c|c|c|c|c|c|}
\hline \multirow{2}{*}{ Horizon } & \multicolumn{2}{|c|}{$\mathrm{pH}$} & C & $\begin{array}{c}\text { Organic } \\
\text { matter }\end{array}$ & P & $\mathrm{Ca}$ & $\mathrm{Mg}$ & K & $H$ & $\mathrm{Al}$ & CEC & V & $\mathrm{m}$ \\
\hline & $\mathrm{H}_{2} \mathrm{O}$ & $\mathrm{KCl}$ & \multicolumn{2}{|c|}{$\mathrm{g} \cdot \mathrm{kg}^{-1}$} & $\mathrm{mg} \cdot \mathrm{dm}^{3}$ & \multicolumn{6}{|c|}{$\mathrm{cmol} \cdot \mathrm{dm}^{-3}$} & \multicolumn{2}{|c|}{$\%$} \\
\hline$A_{1}$ & 6.08 & 5.55 & 10.52 & 18.14 & 20.67 & 3.81 & 12.85 & 2.10 & 2.35 & 0.05 & 21.14 & 88.64 & 0.26 \\
\hline$A B$ & 5.44 & 5.10 & 16.75 & 28.88 & 25.40 & 4.57 & 12.00 & 2.18 & 2.14 & 0.05 & 20.94 & 89.54 & 0.26 \\
\hline $\mathrm{C}_{\mathrm{g}}$ & 4.26 & 4.01 & 26.49 & 45.67 & 19.46 & 4.76 & 12.38 & 2.34 & 4.25 & 0.14 & 23.87 & 81.60 & 3.21 \\
\hline SUSP-01 & - & - & - & - & 86.58 & 2.60 & 0.53 & 1.79 & 1.22 & 0.26 & 6.4 & 76.87 & 5.01 \\
\hline
\end{tabular}




\section{AVAILABILITY OF CHEMICALS UNDER PROLONGED IMMERSION}

The immersion of the soil samples in distilled water for a period of approximately four months provoked alterations in the fertility of the soil and the availability of the elements that function as plant nutrients. The analysis of variance indicated that the alterations were highly significant for all of the parameters studied (Table 2).

The $\mathrm{pH}$ readings (Table 3 and Figure 4A) increase rapidly during the first week, from initial values of less than 4 to moderately acidic values of between 4.1 and 5.6, remaining practically stable - between 5.3 and 5.6 - between the 17th day and the end of the study period. This pattern differs from that of other haplic floodplain gleisols, which were close to neutrality (Silva et al., 1996; Mattar et al., 2002; Lima et al., 2005). The availability of nutrient elements also depends on the $\mathrm{pH}$, given that most macronutrients are found in unavailable forms at low $\mathrm{pH}$. By contrast, the availability of some micronutrients ( $\mathrm{Cu}, \mathrm{Co}, \mathrm{Fe}, \mathrm{Mo}$, and $\mathrm{Zn}$ ) declines substantially at high $\mathrm{pH}$

Table 2. Analysis of variance for the effects of immersion of the soil in the laboratory with distilled water over time (days). Legends: $* * *$ significant $(p<0.01)$; VF = variation factor; DF = degrees of freedom; CV = coefficient of variation.

\begin{tabular}{c|c|c|c|c|c|c|c|c}
\hline $\mathrm{VF}$ & $\mathrm{pH}$ & $\mathrm{Eh}$ & $\mathrm{P}$ & $\mathrm{Ca}$ & $\mathrm{K}$ & $\mathrm{Zn}$ & $\mathrm{Mn}$ & $\mathrm{Fe}$ \\
\hline Days & $* *$ & $* * *$ & $* *$ & $* *$ & $* *$ & $* *$ & $* *$ & $* *$ \\
\hline $\mathrm{DF}$ & 22 & 22 & 22 & 22 & 22 & 22 & 22 & 22 \\
\hline Repetitions & 3 & 3 & 3 & 3 & 3 & 3 & 3 & 3 \\
\hline CV\% & 5.06 & 29.23 & 23.37 & 11.49 & 45.61 & 15.92 & 33.64 & 15.40 \\
\hline
\end{tabular}

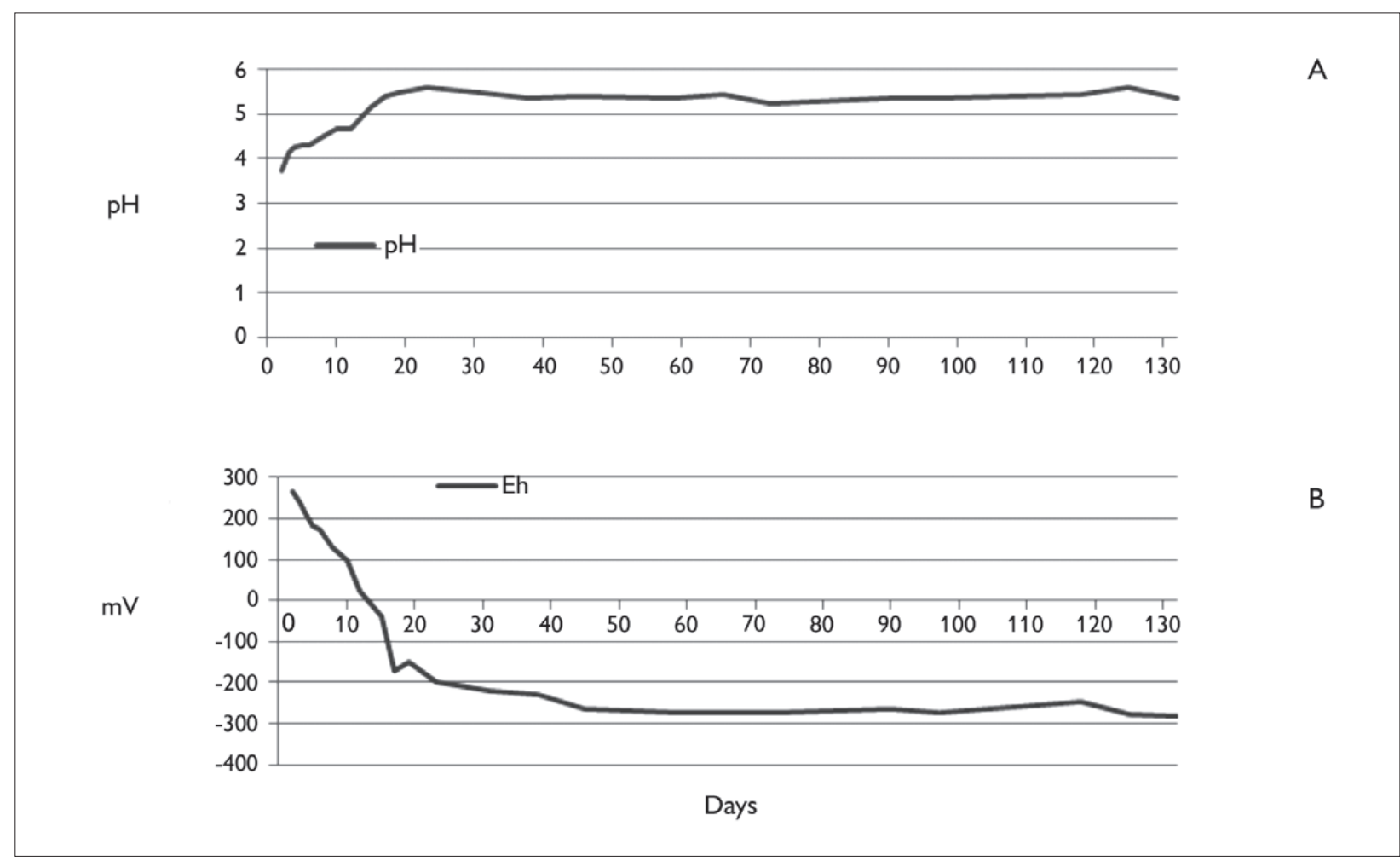

Figure 4. Variation in the mean $\mathrm{pH}(\mathrm{A})$ and $\mathrm{Eh}(\mathrm{B})$ values recorded during the 132 days of immersion.

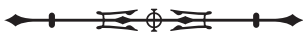


levels. However, the $\mathrm{pH}$ levels recorded in the present study support the availability of most elements considered essential for plant growth (Lopes, 1989).

The Eh readings fell drastically over the first 15 days, in direct contrast with the $\mathrm{pH}$ values, reaching negative levels by the 15th day, and remaining at between -200 and $-300 \mathrm{mV}$ from the 17th day onwards (Table 3, Figure 4B). These values contrast considerably with those recorded for the haplic gleisol of the Guamá estuary, in which the values fell more rapidly to much lower levels, of between -300 and -400 mV (Silva et al., 1996; Silva, 2008). According to Sahrawat (2003), values of Eh of this level indicate the absence of electron acceptors, which impedes the oxidation of organic matter and would account for the accumulation of this material in the mangrove.

Positive values and recorded during the early days of small oscillations are accompanied in dissolved carbon (2.84 to $3.52 \mathrm{~g} / \mathrm{dm}$ ) during the first 15 days of the study, which then decreased linearly until 60 , when it increased again until on day 97, declining again until 115 days (Table 3, Figure 5). After the 14th day, the concentration of dissolved carbon stabilized at a level

Table 3. Mean values obtained from the four experimental mangrove soil samples for $\mathrm{pH}$ and Eh, and the chemical concentrations of available $\mathrm{P}, \mathrm{Ca}, \mathrm{K}, \mathrm{Zn}, \mathrm{Cu}$, and Fe, during immersion with distilled water over a 132-day period, and for organic carbon over 276 days of immersion.

\begin{tabular}{|c|c|c|c|c|c|c|c|c|c|c|}
\hline Day & $\mathrm{pH}$ & $\begin{array}{l}\text { Eh } \\
m V\end{array}$ & $\begin{array}{c}\mathrm{P} \\
\mathrm{mg} / \mathrm{dm}^{3}\end{array}$ & $\begin{array}{c}M n \\
\mathrm{mg} / \mathrm{dm}^{3}\end{array}$ & $\begin{array}{c}\mathrm{Fe} \\
\mathrm{mg} / \mathrm{dm}^{3}\end{array}$ & $\begin{array}{c}\mathrm{K} \\
\mathrm{mg} / \mathrm{dm}^{3}\end{array}$ & $\begin{array}{c}\mathrm{Ca} \\
\mathrm{mg} / \mathrm{dm}^{3}\end{array}$ & $\underset{\mathrm{mg} / \mathrm{dm}^{3}}{\mathrm{Zn}}$ & Day & $\underset{\mathrm{g} / \mathrm{dm}^{3}}{\mathrm{C}}$ \\
\hline 1 & 3.73 & 266 & 103.18 & 14 & 1168.25 & 0.15 & 353 & 3 & 1 & 2.84 \\
\hline 2 & 4.13 & 240.25 & 105.28 & 6 & 1284 & 0.15 & 369.25 & 4.25 & 14 & 3.52 \\
\hline 3 & 4.25 & 214.5 & 111.49 & 7.75 & 1387.75 & 0.67 & 342.25 & 3.5 & 30 & 2.38 \\
\hline 4 & 4.29 & 182.5 & 110.62 & 7 & 1311.5 & 1.31 & 348.5 & 3 & 38 & 2.29 \\
\hline 5 & 4.31 & 172 & 142.4 & 8 & 1720.25 & 1.31 & 279 & 2.5 & 60 & 1.52 \\
\hline 8 & 4.48 & 131 & 136.31 & 6.75 & 1408.75 & 0.67 & 291.25 & 3 & 81 & 1.98 \\
\hline 10 & 4.65 & 100.25 & 148.36 & 8 & 1850 & 0.15 & 289.75 & 4.25 & 97 & 2.10 \\
\hline 12 & 4.67 & 24 & 173.43 & 9.25 & 2084.5 & 0.39 & 456.75 & 3.25 & 115 & 1.18 \\
\hline 15 & 5.13 & -39.75 & 33.04 & 6.75 & 1606.25 & 1.29 & 476.25 & 3.25 & 133 & 2.64 \\
\hline 17 & 5.41 & -170 & 35.89 & 5.25 & 2429.75 & 1.92 & 442 & 3.75 & 170 & 2.00 \\
\hline 19 & 5.49 & -147.75 & 45.63 & 8.5 & 2386 & 2.62 & 461.5 & 5.25 & 187 & 2.10 \\
\hline 23 & 5.59 & -200 & 50.77 & 7.5 & 2410 & 1.51 & 389 & 2.25 & 202 & 0.89 \\
\hline 31 & 5.48 & -221.75 & 144.05 & 9 & 1549 & 1.29 & 400 & 4.25 & 221 & 0.38 \\
\hline 38 & 5.37 & -228.5 & 87.2 & 10.75 & 2133.75 & 1.43 & 373 & 4 & 276 & 1.43 \\
\hline 45 & 5.39 & -262.5 & 66.12 & 4.75 & 4450.5 & 1.28 & 278 & 6.75 & & \\
\hline 59 & 5.37 & -273.5 & 48.92 & 5.75 & 5074.75 & 0.96 & 496 & 4.75 & & \\
\hline 66 & 5.44 & -271.25 & 67.63 & 12.5 & 5136.5 & 1.32 & 348.25 & 2.25 & & \\
\hline 73 & 5.25 & -272.25 & 69.74 & 10.25 & 4252 & 1.09 & 439.25 & 4 & & \\
\hline 90 & 5.35 & -264.5 & 50.12 & 11.75 & 4701.75 & 1.22 & 493 & 5.25 & & \\
\hline 97 & 5.36 & -275 & 38.03 & 11.25 & 3929 & 1.39 & 407.25 & 4.75 & & \\
\hline 118 & 5.43 & -247 & 53.7 & 12.75 & 2184 & 1.27 & 552.25 & 6.75 & & \\
\hline 125 & 5.6 & -279 & 56.78 & - & 2799 & 1.43 & 543 & 6.25 & & \\
\hline 132 & 5.34 & -281.25 & 52.46 & - & 2451 & 1.24 & 546 & 6.5 & & \\
\hline
\end{tabular}


of around $2.0 \mathrm{~g} / \mathrm{dm}^{3}$. The pattern of variation in this component was roughly parallel to that observed in the Eh values, that is, as this parameter stabilized, so did the carbon concentrations, a pattern also seen in the $\mathrm{pH}$ readings. Overall, then, the conditions of the experiment remained relatively stable from the 15-17th day onwards, with a general tendency for an anoxic environment. The determination of organic carbon lasted until 276 days of flooding, proving their consumption, although not completely consuming (Figure 5).
The average concentration of phosphorus increased considerably over the first 10 days, from 103.18 $\mathrm{mg} / \mathrm{dm}$ of $148.36 \mathrm{mg} / \mathrm{dm}$, butthen quickly fell by 23 , reaching $50.77 \mathrm{mg} / \mathrm{dm}$, and then rising sharply again at 114.05 $\mathrm{mg} / \mathrm{dm}^{3}$ per day at 31, and finally stabilized at between 50 and $75 \mathrm{mg} / \mathrm{dm}$ until the end of the study period (Table 3 , Figure 6). Overall, this pattern is consistent with the amounts and concentrations of the dissolved carbon, that is, together with the $\mathrm{pH}$, define the environment. It seems likely that phosphorus liberated was derived from oxy-

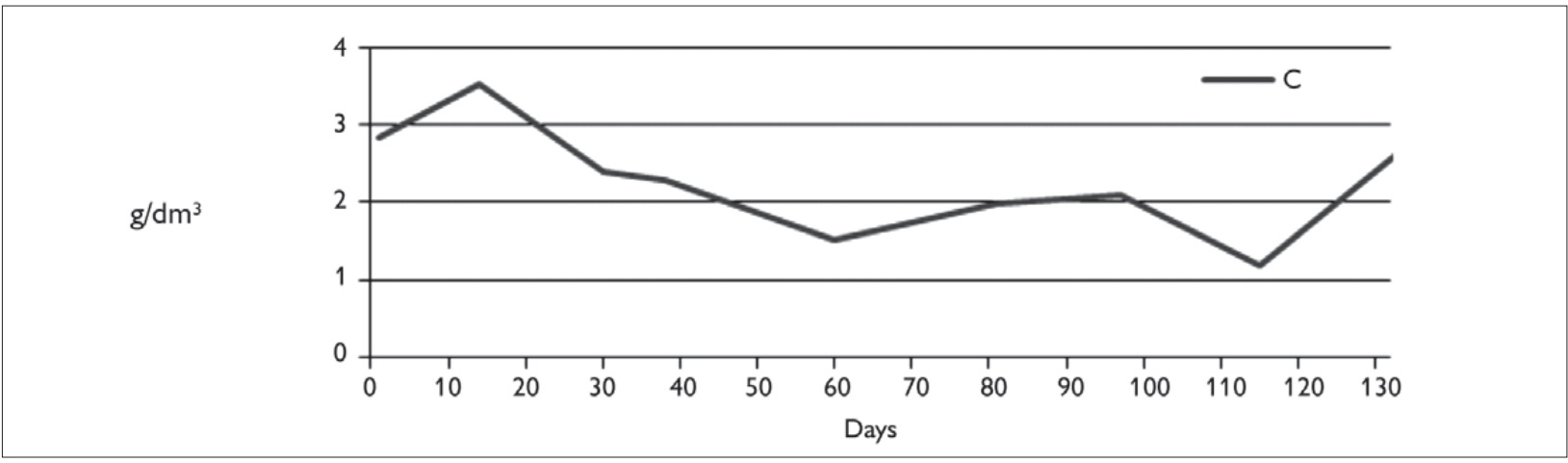

Figure 5. Variation in the mean concentrations of dissolved organic carbon over the 132 days of immersion.

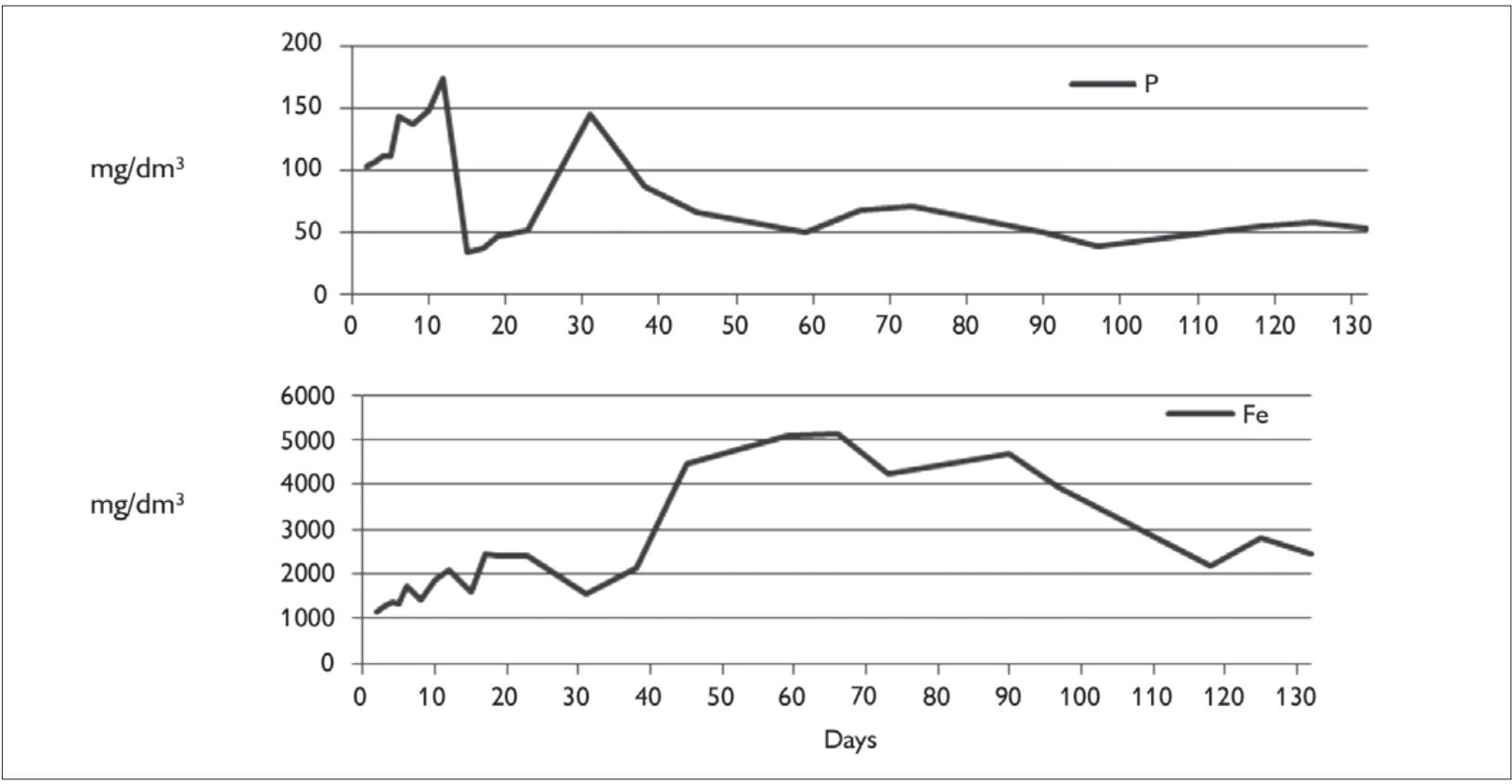

Figure 6. Variation in the mean concentrations of iron and available phosphorus over the 132 days of immersion.

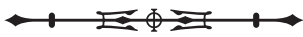


ferrous hydroxides, abundant in the region, which became unstable with the environment has become increasingly small, consuming the organic material.

A similar pattern was recorded for the phosphorus content of haplic gleisols from the same region in a similar experiment (Silva et al., 1996; Mattar et al., 2002; Silva, 2008). Mello et al. (1992) recorded the presence of this element in ferrous oxy-hydroxides, such as ferrihydrite, lepidocrocite, and goethite, and Lima et al. (2005) found larger quantities of phosphorus liberated in 11 different soils containing these minerals in reducing conditions in the Amazon basin. These minerals were not detected by XRD, although this does not mean that they were completely absent. In an analysis of the mangrove soil of the Marapanim River, in the same region (Salgado zone), Silva (2005) only observed oxy-hydroxides covering the quartz in the form of a thin film. The immobilization of the phosphorus may occur through its co-precipitation as ferrous phosphate, that is, vivianite, $\mathrm{Fe}_{3}\left(\mathrm{PO}_{4}\right)_{2} \cdot 8 \mathrm{H}_{2} \mathrm{O}$ (Chancon et al., 2006).

The diagrams of binary dispersal and the Pearson correlation coefficients (Table 4 and Figure 7) indicated that the phosphorus content correlated in a linear fashion with that of iron only at the lower P values $\left(20-70 \mathrm{mg} / \mathrm{dm}^{3}\right.$ ) and higher Fe values, which corresponds to the period of the experiment when the environment appeared to have stabilized (Figures 4, 5, and 6). Overall, the correlations tended to be negative, while there was no correlation with $\mathrm{Ca}$ and $\mathrm{Mn}$ (Table 4). This suggests that the phosphorus is being liberated by the ferrous minerals, when decomposed in the anoxic environment, as shown previously. The chemical analyses of the soluble fraction of the suspended material indicated that the available phosphorus is relatively abundant (Table 1), which indicates that the suspended material may be contributing to the introduction of soluble phosphorus into the mangrove during the high tide, as a periodic contribution to this system.

In broad terms, the concentrations of soluble iron increased steadily until the 90th day, but reached a maximum value of $5136.5 \mathrm{mg} / \mathrm{dm}^{3}$ on the 66th day,
Table 4. Pearson's linear correlation coefficients for the concentrations of $\mathrm{P}, \mathrm{Ca}, \mathrm{Mn}$, and Fe recorded in the gleisol immersed during the present experiment $(n=40)$. Legends: $* *$ significant $(p<0,01)$; ns $=$ not significant $(p>0,05)$.

\begin{tabular}{c|c|c|c|c}
\hline & $P$ & $\mathrm{Ca}$ & $\mathrm{Mn}$ & $\mathrm{Fe}$ \\
\hline $\mathrm{P}$ & 1 & $-0.3688^{* * *}$ & $-0.0855^{\mathrm{ns}}$ & $0.4209^{* *}$ \\
\hline $\mathrm{Ca}$ & $0.3164^{* *}$ & 1 & $0.5450^{* * *}$ & $0.5450^{* *}$ \\
\hline $\mathrm{Mn}$ & $0.3164^{* *}$ & $-0.2766^{* *}$ & 1 & $-0.2762^{* *}$ \\
\hline $\mathrm{Fe}$ & $-0.8201^{* *}$ & $-0.0835^{* *}$ & $-0.0342^{* *}$ & 1 \\
\hline
\end{tabular}

decreasing abruptly to $1549 \mathrm{mg} / \mathrm{dm}^{3}$ on the 31st day (Table 3, Figure 6). Between the 90th day and the end of the experiment, the values decreased to $2451 \mathrm{mg} / \mathrm{dm}^{3}$. This pattern is practically the opposite of that of the $\mathrm{Fe}$, as shown above. This indicates that Fe was solubilized continuously throughout most of the experiment, suggesting that the oxy-hydroxide minerals of this element become unstable in the anoxic environment, and probably only begin to precipitate as sulfides from the 95th day onwards, or when the oxy-hydroxides were exhausted. The dissolution of the iron oxy-hydroxides in anoxic environments, such as mangroves and freshwater swamps, has been well documented (Silva et al., 1996; Ferreira et al., 1998; Ferreira \& Botelho, 1999; Mattar et al., 2002; Silva, 2008) as has the consequent precipitation of iron sulfides (Costa et al., 2004; Vilhena et al., 2010; Sherman et al., 1998; Prada-Gamero et al., 2004). The levels of soluble iron recorded in this study may be considered toxic for most plants, for which concentrations of over $600 \mathrm{mg} / \mathrm{dm}^{3}$ may be deleterious (Fageria, 1984).

The levels of soluble $\mathrm{Mn}$ recorded during the experiment were relatively low (Table 3, Figure 8), indicating the absence of manganese minerals or the presence of stable $\mathrm{Mn}$ minerals in the natural environment. However, Mn minerals were not identified by $X R D$, and the levels of total $\mathrm{MnO}$ in the samples analyzed were below mean crustal values $(0.01 \%)$. Clearly, then, no manganese minerals were present in the soil investigated in the present study. Despite these extremely low values of soluble $\mathrm{Mn}$, it was possible to identify a gradual increase 
during the course of the experiment, following an abrupt decrease on the second day of observation, with values of around $10 \mathrm{mg} / \mathrm{dm}^{3}$ until the 31st day, with abrupt reductions on the 45th and 59th days, followed by a gradual, but oscillating increase until the end of the experimental, reaching a maximum value of $12.75 \mathrm{mg} / \mathrm{dm}^{3}$ by the 118th day. These relatively low quantities may have been liberated by the ferrous oxy-hydroxides. The reduction observed between the 45th and 60th days may represent the precipitation of $\mathrm{MnCO}_{3}$ (rhodochrosite) or as $\mathrm{FeCO}_{3}$, siderite (Sanchez, 1981), but the extremely low values do not support this conclusion. The concentrations of dissolved manganese $\left(6-14 \mathrm{mg} / \mathrm{dm}^{3}\right)$ are considerably lower than those observed in the haplic gleisol of the Guamá River, in the Amazon estuary, which ranged from 100 to $300 \mathrm{mg} / \mathrm{dm}^{3}$ (Silva et al., 1996).

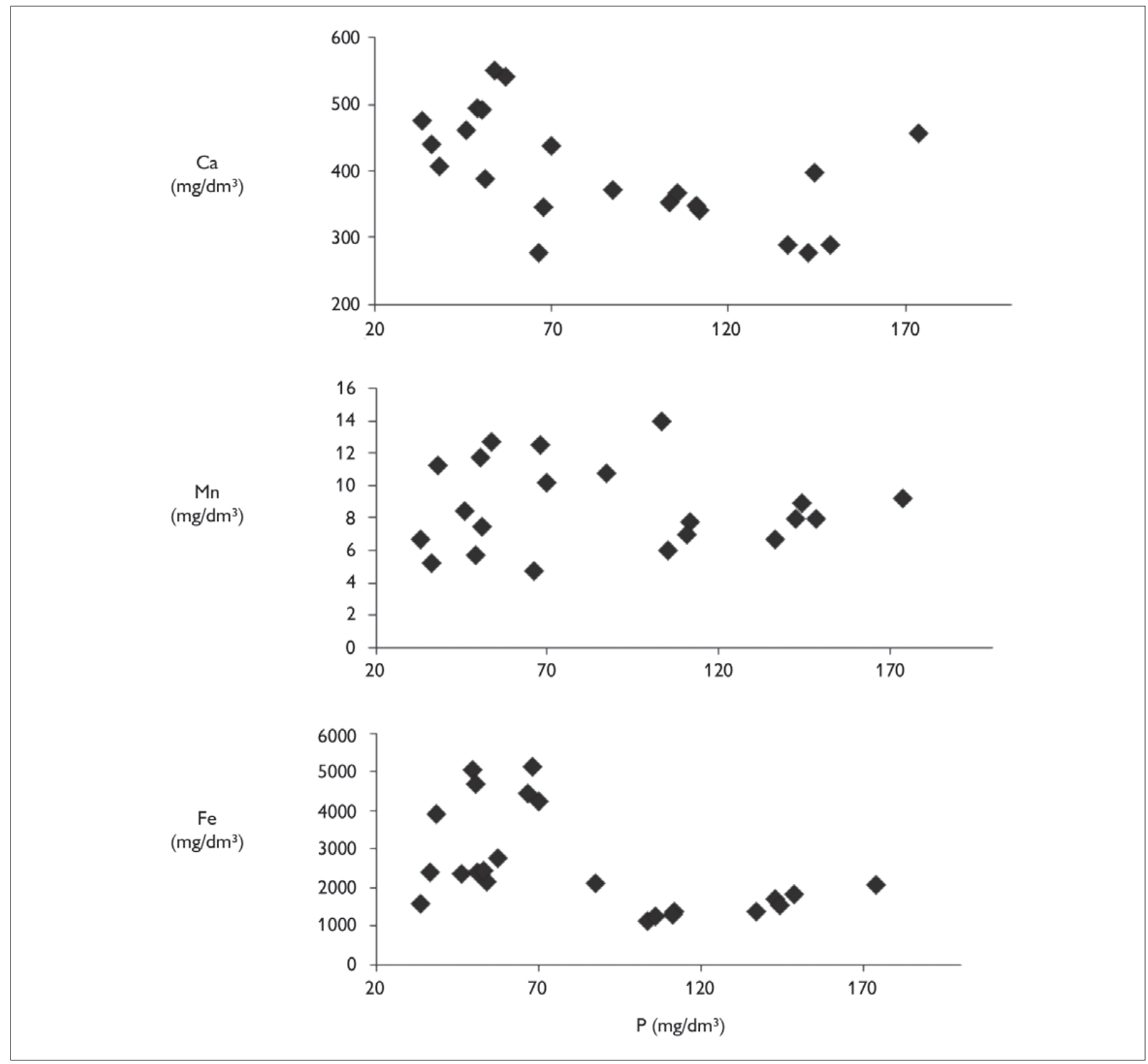

Figure 7. Binary dispersal diagrams for the soluble concentrations of $\mathrm{P}$ and $\mathrm{Fe}, \mathrm{P}$ and $\mathrm{Ca}$, and $\mathrm{P}$ and $\mathrm{Mn}$.

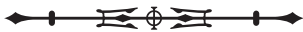


In general, the concentrations of soluble zinc were distributed in a manner similar to those of $\mathrm{Mn}$, but with much lower values, which were expected, given that this is a trace element and is thus much less abundant in the Earth's crust. The only distinction was observed in the period between the 45th and the 59th days, when, in contrast with $\mathrm{Mn}$, there was an abrupt increase in the values, but then a marked reduction on the 66th day, when it reached $2.25 \mathrm{mg} / \mathrm{dm}^{3}$. Overall, the values for Zn were between $2.25 \mathrm{mg} / \mathrm{dm}^{3}$ and $6.75 \mathrm{mg} / \mathrm{dm}^{3}$ (Table 3, Figure 8). Ponnamperuma (1972), Neue \& Mamaril (1985), and Fageria et al. (2011) all observed the exactly opposite pattern, that is, a reduction in the availability of $\mathrm{Zn}$ with increasing $\mathrm{pH}$, which favors the precipitation of $\mathrm{Zn}(\mathrm{OH})_{2}$ (wülfingite) and/or $\mathrm{ZnCO}_{3}$ (smithsonite) through the accumulation of $\mathrm{CO}_{2}$ resulting from the decomposition of organic material. Alternatively, the precipitation of $\mathrm{ZnS}$ would be favored under highly reducing conditions. In the present case, the extremely low values recorded for zinc $\left(<6.75 \mathrm{mg} / \mathrm{dm}^{3}\right)$ would be insufficient for the formation of these compounds, especially in the anoxic environment that prevailed during most of the experiment. The low levels of available zinc may indicate the absence of minerals containing this element that are unstable in this type of environment. As in the case of $\mathrm{Mn}$, the overall levels of $\mathrm{Zn}$ in the soil (10 ppm) are lower than crustal values, that is, they are of reduced significance.

Like phosphorus, calcium and potassium are primary macronutrients, and are thus required by plants in relatively large quantities. In this immersion experiment, the concentrations of these two elements varied in a similar fashion until the 45th day, that is, increasing erratically until the 20th day and then decreasing until the 45th day. From this point onwards, the availability of $\mathrm{Ca}$ increased erratically, whereas $\mathrm{K}$ varied less, with a slight tendency to decrease overall. The levels of Ca (278-552 mg/dm² Table 1, Figure 8) are approximately 200 times greater than those of $\mathrm{K}\left(0.15-2.92 \mathrm{mg} / \mathrm{dm}^{3}\right.$ : Table 1, Figures 9A and 9B). However, these levels, even those of $\mathrm{K}$, are adequate for plant nutrition (Lopes \& Guilherme, 2005).

Potassium was nevertheless only available during the first 19 days of the experiment, when it increased from $0.15 \mathrm{mg} / \mathrm{dm}^{3}$ to $2.62 \mathrm{mg} / \mathrm{dm}^{3}$ (Table 1, Figure 9). The total concentration of $\mathrm{K}_{2} \mathrm{O}$ in the soil was $0.72 \%$, although this reduced availability reflects the presence of the principal potassium-bearing mineral identified by $X R D$, illitemuscovite, which is of reduced solubility in soils (Loughnan, 1969; Mohr et al., 1972; Plas \& Schuylenborgh, 1970).

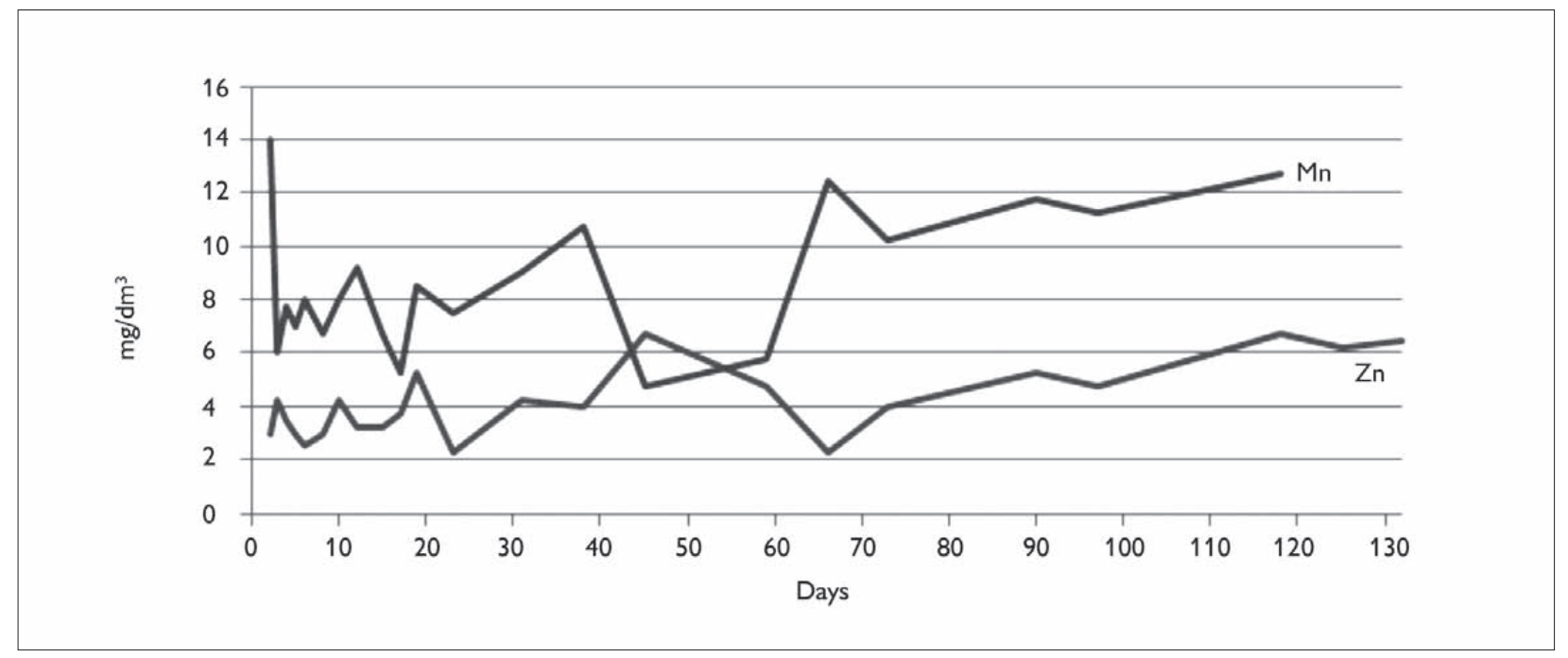

Figure 8. Variation in the mean concentrations of exchangeable manganese and zinc made available during the 132 days of immersion.

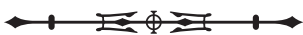




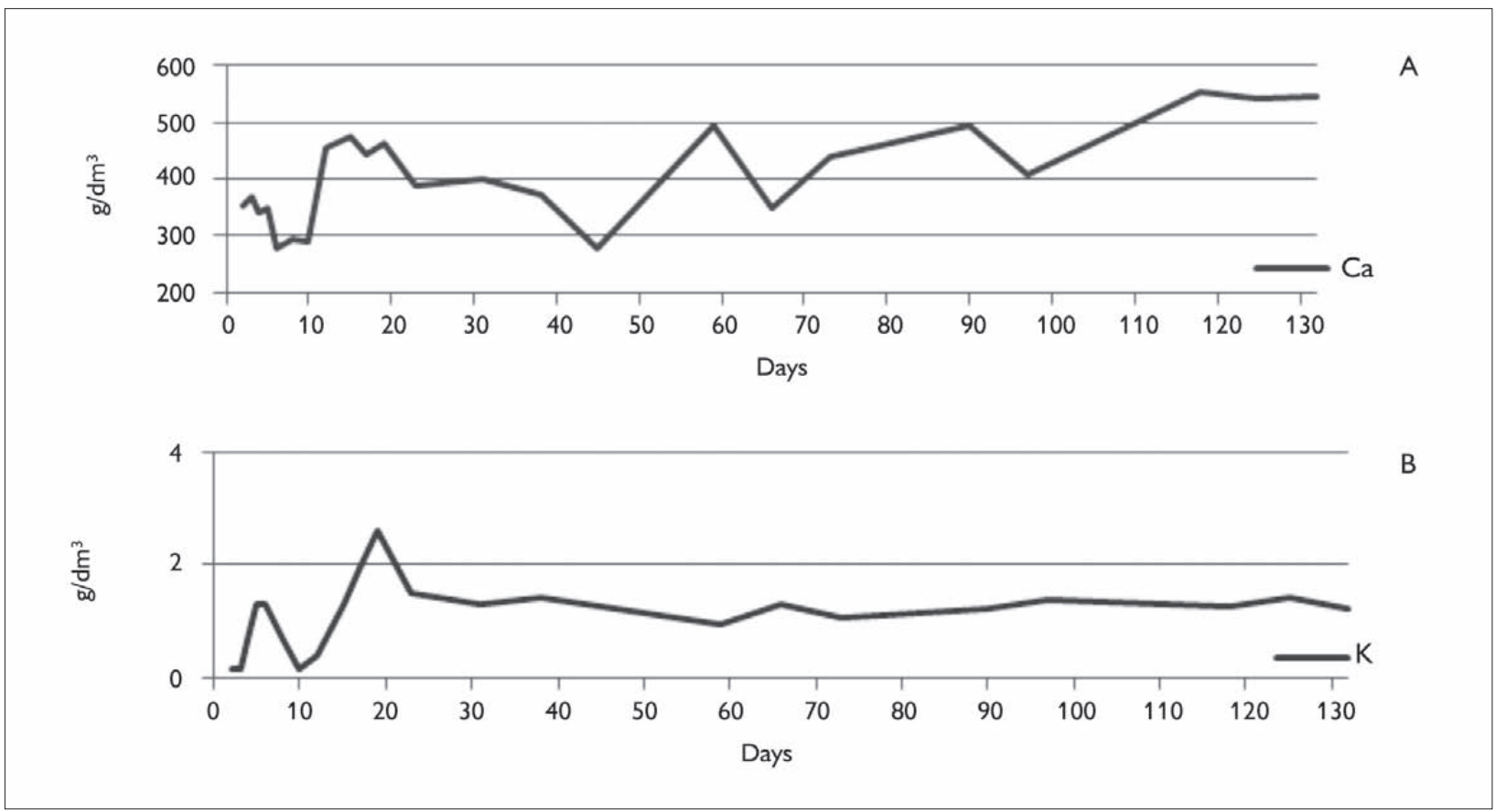

Figure 9. Variation in the mean concentrations of calcium (A) and exchangeable potassium (B) released during the 132 days of immersion.

The decreased availability of $\mathrm{Ca}$ in the first 10 days, when Eh was oxidizing, and the $\mathrm{pH}$ acidic, may reflect the consumption of $\mathrm{Ca}$ for the formation of the carapaces of the crustaceans found in this environment. In the specific case of the present experiment, the absence of these organisms from the environment, may have led to the precipitation of this element as inorganic $\mathrm{CaCO}_{3}$. The increasing availability of this element after the 45th day, when Eh was already negative, and the environment was reducing and less acidic, may represent the solubilization of the Ca carbonates, either precipitated or found in the carapace fragments. The oscillations towards lower values may represent the variations in the environment indicated by the fluctuating values for Eh, $\mathrm{pH}$, and dissolved carbon. The total level of $\mathrm{CaO}$ in the soil was comparatively high $(0.72 \%)$ and the available concentration was also relatively high, reaching $552 \mathrm{mg} / \mathrm{dm}^{3}$, which indicates that the element may be derived from minerals of high solubility, such as $\mathrm{Ca}$ carbonates, calcite or aragonite, the principal components of mangrove organisms, which were solubilized during the course of the experiment, which provided environmental conditions favorable to this process (Suguio, 1980; Chou et al., 1988; Liang et al., 1996).

\section{CONCLUSIONS}

The salic gleisol of the Bragança region is highly fertile, with a predominance of negative charges, which are mostly occupied by elements that are plant nutrients. The high CEC and high levels of base saturation recorded in the study indicate the presence of a eutrophic environment for plants. In addition, the reduced participation of aluminum in the exchange complex is confirmed by the saturation of extremely low levels of this element $(0.26 \%)$. This permits the occupation of the exchange sites by the cations essential to plant nutrition. The mineralogical composition of the soil, with high concentrations of smectite and illite, which are also found in the suspended material, favors increased CEC.

In comparison with the haplic gleisol of the tidal floodplain of the Guamá River in the vicinity of the city

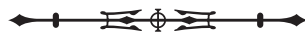


of Belém, the samples analyzed in the present study were characterized by their higher fertility, and features such as the stabilization of the $\mathrm{pH}$ following immersion, moderate acidity, and high levels of organic material in the soil profile, much higher than those recorded in the haplic gleisols (Silva et al., 1996; Mattar et al., 2002; Silva, 2008). The Eh of this salic gleisol was also $100 \mathrm{mV}$ lower than that of the haplic gleisol of the Guamá indicating that the reduction is interrupted at a certain point, leading to an accumulation of organic carbon. While this does not favor an increase in the $\mathrm{pH}$ towards neutrality, the presence of this organic material is advantageous in terms of the fertility of the soil.

The organic material must also be contributing to the formation of the CEC and thus providing the available phosphorus for this mechanism. However, the principal source of phosphorus appears to be the unstable ferrous oxyhydroxides present under the dominant anoxic conditions.

The experiment showed that the soil responded to the addition of distilled water through modifications in the environment and its fertility. While the $\mathrm{pH}$ values stabilized at between 5 and 6, which are acidic values, this permits the decomposition of the minerals that form soils, making the elements essential to plant growth available. The quantities liberated into the soil were beneficial, even in the case of potassium, which was available in the smallest, but nevertheless adequate quantities. The concentrations of $\mathrm{Mn}$, which responds to reductive processes in anoxic environments, were relatively low in comparison with those recorded in haplic gleisol (Silva et al. 2015), but once again, at adequate levels, considering that plants require extremely small quantities of this element.

Overall, the organic material and 2:1 clay minerals present in this mangrove environment constitute important determinants of the soil's fertility. The solubilized ferrous oxy-hydroxides were equally important as a source of $P, M$, and $\mathrm{Zn}$. The primary source of the inorganic components of the salic gleisol is the suspended material of the Caeté River, which are fed into the mangroves on the tide.
The mapping of boundaries between the swamp and floodplain, and their features, the Community have used for rice production, may encourage the planting of this species to provide this food to the population.

\section{ACKNOWLEDGMENTS}

We are grateful to the technicians of the UFRA Soil Laboratory for their assistance with the soil analyses and those of the UFPA Chemical Analyses Laboratory for their support during the development of the experiment, and the UFRA field team for their help with the collection of the samples analyzed here. We also thank the graduate program of the UFPA Geosciences Institute for logistic support for the collection of samples and providing resources for the chemical analyses.

\section{REFERENCES}

ASSIS, M. P., J. G. CARVALHO, N. CURI, J. C. BERTONI \& W. E. B. ANDRADE, 2000. Limitações nutricionais para a cultura do arroz em solos orgânicos sob inundação. I. Crescimento. Ciência Agrotécnica 24(1): 87-95.

BERREDO, J. F., M. L. COSTA \& M. P. S. P. VILHENA, 2008. Efeitos das variações sazonais do clima tropical úmido sobre as águas e sedimentos de manguezais do estuário do rio Marapanim, costa nordeste do estado do Pará. Acta Amazonica 38(3): 473-482.

BURKE, L., Y. KURA, K. KASSEM, C. REVENGA, M. SPALDING \& D. MCALLISTER, 2001. Pilot analysis of global ecosystems: coastal ecosystems: 1-77. World Resources Institute, Washington.

CAMARGO, F. A. O., G. A. SANTOS \& E. ZONTA, 1999. Alterações eletroquímicas em solos inundados. Ciência Rural 29(1): 171-180.

CHANCON, N., S. FLORES \& A. GONZALEZ, 2006. Implications of iron solubilization on soil phosphorus release in seasonally flooded forests of lower Orinoco River, Venezuela. Soil Biology and Biochemistry 38(6): 1494-1499.

CHMURA, G. L., S. C. ANISFELD, D. R. CAHOON \& I. C. LYNCH, 2003. Global carbon sequestration in tidal, saline wetland soils. Global Biogeochemical Cycles 17(4): 1-12.

CHOU, L., R. M. GARRELS \& R. WOLLAST, 1988. Comparative study of dissolution kinetics and mechanisms of carbonates in aqueous solutions. Chemical Geology 70(1-2): 1-77.

CITRÓN, G. \& Y. SCHAEFFER-NOVELLI, 1983. Introducción a la ecologia del manglar: 1-109. Rostlac, San Juan.

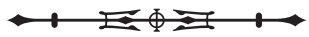


COSTA, M. L., H. BEHLING, J. F. BERRÊDO \& M. S. C. CARMO, 2004. Mineralogical, geochemical and palynological studies of late holocene mangrove sediments from northeastern Pará state, Brazil. Revista Brasileira de Geociências 34(4): 479-488.

EMPRESA BRASILEIRA DE PESQUISA AGROPECUÁRIA (EMBRAPA), 1997. Manual de métodos de análise de solo: 2. ed.: 1-212. Centro Nacional de Pesquisa de Solos, Rio de Janeiro.

FAGERIA, N. K., 1984. Adubação e nutrição mineral da cultura do arroz: 1-341. Campus/EMBRAPA, Rio de Janeiro/Goiânia.

FAGERIA, N. K., G. D. CARVALHO, A. B. SANTOS, E. P. B. FERREIRA \& A. M. KNUPP, 2011. Chemistry of lowland rice soils and nutrient availability. Communications in Soil Science and Plant Analysis 42(16): 1913-1933.

FERREIRA, W. A., M. S. MODESTO JÚNIOR, S. M. BOTELHO \& R. E. B. MASCARENHAS, 1998. Efeito da inundação sobre as propriedades de um glei pouco húmico de várzea do rio Guamá, nos municípios de Belém e Santa Izabel, PA: 1-29. EMBRAPACPATU (Boletim de Pesquisa, 207), Belém.

FERREIRA, W. A. \& S. M. BOTELHO, 1999. Efeito da inundação sobre as propriedades de um gleissolo sálico sódico de várzea do rio dos Morcegos, no município de Primavera, PA: 1-24. EMBRAPA Amazônia Oriental (Boletim de Pesquisa, n. 21), Belém.

FERREIRA, T. O., P. VIDAL-TORRADO \& X. L. OTERO, 2007. Are mangrove forest substrates sedments or soil? A case study in southeastern Brazil. CATENA 70(1): 79-91.

FURTADO, L. G., I. H. NASCIMENTO, G. SANTANA \& M. C. MANESCHY, 2006. Formas de utilização de manguezais no litoral do estado do Pará: casos de Marapanim e São Caetano de Odivelas. Amazônia: Ciência \& Desenvolvimento 1(2): 113-127.

KRISTENSEN, E., S. BOUILLON, T. DITTMAR \& C. MARCHAND, 2008. Organic carbon dynamics in a mangrove system: a review. Aquatic Botany 89: 201-219.

LIANG, L., D. R. BAER, J. M. MCCOY, J. E. AMONETTE \& J. P. LAFEMINA, 1996. Dissolution kinects at calcite-water interface. Geochimica et Cosmochimica Acta 60(23): 4883-4887.

LIMA, H. N., J. W. V. MELLO, C. E. G. R. SCHAEFER \& J. C. KER, 2005. Dinâmica da mobilização de elementos em solos da Amazônia submetidos à inundação. Acta Amazonica 35(3): 317-330.

LIMA, R. R. \& M. M. TOURINHO, 1995. Várzeas do nordeste paraense e pré-Amazônia maranhense: características e possibilidades agropecuárias: 1-80. FCAP, Belém.

LIMA, R. R., M. M. TOURINHO \& J. P. C. COSTA, 2001 Várzeas flúvio-marinhas da Amazônia brasileira: características e possibilidades agropecuárias: 1-342. FCAP, Belém.
LOPES, A. S., 1989. Manual de fertilidade do solo: 1-155. ANDA/ POTAFOS, São Paulo.

LOPES, A. S. \& L. R. G. GUILHERME, 2005. Interpretação da análise de solo: conceitos e aplicações: 1-50. Associação Nacional para Difusão de Adubos (Boletim Técnico n² 2), São Paulo.

LOUGHNAN, F. C., 1969. Chemical weathering of silicate minerals. Elsevier Publishing Company, New York.

MATTAR, R. M. V. C., L. S. VIEIRA \& G. R. SILVA, 2002. Efeito da inundação sobre o $\mathrm{pH}$ e a disponibilidade de fósforo, sódio, ferro e manganês em um Gley Pouco Húmico coletado na várzea do rio Guamá, Belém (PA). Revista de Ciências Agrárias (37): 113-121.

MELLO, J. W. V., M. P. F. FONTES, A. C. RIBEIRO \& V. V. H. ALVAREZ, 1992. Inundação e calagem em solos de várzea: I. Alterações em pH, Eh, e teores de $\mathrm{Fe}^{2+}$ e $\mathrm{Mn}^{2+}$ em solução. Revista Brasileira de Ciência do Solo 16: 309-317.

MOHR, E. C. J., F. A. VAN BAREN \& J. V. VAN SCHUYLENBORGH, 1972. Tropical soils: a comprehensive study of their genesis: 1-461. The Hage, Mouton.

MOORE, D. M. \& R. C. REYNOLDS JR., 1997. X-ray diffraction and the identification and analysis of clay minerals: 2. ed.: 1-378. Oxford University Press, New York.

NEUE, H. E. \& C. P. MAMARIL, 1985. Zinc, sulfur, and other micronutrients in wetland soils. In: INTERNATIONAL RICE RESEARCH INSTITUTE (Ed.): Wetland soils: characterization, classification and utilization: 307-320. IRRI, Los Baños, Philippines.

OTERO, X. L., T. O. FERREIRA, M. A. HUERTA-DIAZ, C. S. M. PARTITI, V. SOUZA JR., P. VIDAL-TORRADO \& F. MACIAS, 2009. Geochemistry of iron and manganese in soils and sediments of a mangrove system, Island of Pai Matos (Cananeia - SP, Brazil). Geoderma 148(3-4): 318-335.

PLAS, L. V. D. \& J. V. SCHUYLENBORGH, 1970. Petrochemical calculations applied to soils - with a special reference to soil formation. Geoderma 4(4): 357-385.

PONNAMPERUMA, F. N., 1972. The chemistry of submerged soils. Advances in Agronomy 24: 29-96.

PRADA-GAMERO, R. M., P. VIDAL-TORRADO \& T. O. FERREIRA, 2004. Mineralogia e físico-química dos solos de mangue do rio Iriri no canal de Bertioga (Santos, SP). Revista Brasileira de Ciência do Solo 28: 233-243.

SAHRAWAT, K. L., 2003. Organic matter accumulation in submerged soil. Advances in Agronomy 81: 169-201.

SANCHEZ, P. A., 1981. Suelos del tropico: características y manejo. IICA, San Jose.

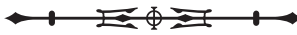


SHAEFFER-NOVELLI, Y., 1999. Avaliação e ações prioritárias para a conservação da biodiversidade da zona costeira e marinha: 1-56. USP, São Paulo.

SHERMAN, R. E., T. J. FAHEY \& R. W. HOWARTH, 1998. Soil-plant interactions in a neotropical mangrove forest: iron, phosphorus and sulfur dynamics. Oecologia 115(4): 553-563.

SILVA, J. F. B. R., 2005. Geoquímica dos sedimentos dos manguezais do nordeste do estado do Pará: o exemplo do estuário de Marapanim: 1-198. Tese (Doutorado em Geoquímica) - Universidade Federal do Pará, Belém.

SILVA, P. A. L. S., 2008. Efeito da inundação sobre o enxofre e outros atributos químicos de um Gleissolo Háplico da várzea do rio Guamá, Belém-PA: 1-60. Dissertação (Mestrado em Agronomia) - Universidade Federal Rural da Amazônia, Belém.

SILVA, F. C., 2009. Manual de análises químicas de solos, plantas e fertilizantes: 2. ed.: 1-627. EMBRAPA Informação Tecnológica, Brasília.

SILVA, G. R., P. A. L. SILVA, S. B. SILVA, M. L. SILVA JR., M. A. P. GAMA \& A. R., FERNANDES, 2015. Eletrochemical changes in gleysol of the Amazon estuary. Amazonian Journal of Agricultural and Environmental Sciences 58(2): 152-158.
SILVA, S. B., L. V. VIEIRA \& W. A. FERREIRA, 1996. Avaliação da disponibilidade de nutrientes em várzea inundada do Rio Guamá: 1-18. FCAP (Informe Técnico, 18), Belém.

SOUZA FILHO, P.W. M., 2005. Costa de manguezais de macromaré da Amazônia: cenários morfológicos, mapeamento e quantificação de áreas usando dados de sensores remotos. Revista Brasileira de Geofísica 23(4): 427-435.

SUGUIO, K., 1980. Rochas sedimentares: propriedades, gênese, importância econômica: 1-500. E. Blücher/Edusp, São Paulo.

VILHENA, M. P. S. P., M. L. COSTA \& J. F. BERREDO, 2010. Continental and marine contribuitions to formations os mangrove sedments in an Eastern Amazônia mudplain: the case of Marapanim Estuary. Jornal of South America Earth Sciences 29: 427-438. 
